\title{
Development of A Children Worth City Based on Collaborative Governance In Kediri City
}

\author{
Indasah, Herry Krismono, Heri Saputro* \\ Institut Ilmu Kesehatan STRADA Indonesia, Kediri, Indonesia \\ *h.saputro@iik-strada.ac.id
}

\begin{abstract}
Child Friendly City is an effort to transform the Convention on the Rights of the Child from the legal framework of the Child Protection Act into the definitions, strategies for Mainstreaming the Rights of the Child and development interventions, in the form of Policies, Institutions, programs and development activities intended for the fulfillment of children's rights in a Regency / City area. The point is the creation of districts / cities where children can grow and develop optimally and are protected from violence and discrimination. In order to anticipate the failure of potentials that can disrupt the process of city development worthy of children, the government needs to change the pattern of governance by strengthening through cooperation and developing a model of communication processes and joint actions with other institutions. This study aims to 1) map the main problems of children in the development and potentials that exist in the regions from the aspects of policies, institutions / organizations of children that can be developed; 2) developing a collaborative governance model in the development of child-friendly cities in the City of Kediri. This research method uses descriptive qualitative using primary and secondary data. The results of the study describe the occurrence of child problems including information facilities for children, age of marriage under 18 years due to pregnancy, lack of optimal functioning of the consultation agency for parents, lack of mechanisms for monitoring victims of violence against children, decreasing rates of exclusive breastfeeding, and the absence of paying the law of several agencies. The potential of regional policies in the form of regional regulations, the number of children's social institutions is a strong social capital physically and socially in building a collaborative model / partnership.
\end{abstract}

Keywords: Children, Collaboration, Policy, Programs 


\section{STRADA Jurnal Ilmiah Kesehatan}

DOI: $10.30994 /$ sjik.v9i2.535

ISSN: 2252-3847 (print); 2614-350X (online)

Vol.9 No.2 November 2020 Page. 1788-1796

\section{BACKGROUND}

Since the beginning, Indonesia has been very intensively involved and committed in the formulation of the fulfillment of children's rights through the CRC by ratifying the CRC with Presidential Decree No. 36 th 1990. Considering that the World Fit for Children is a global commitment, the Government of Indonesia immediately gave a positive response to the UN General Assembly recommendation in 2002. Efforts to realize a Child-Friendly Indonesia began with the passage of Law Number 23 of 2002 concerning Child Protection on October 22, 2002. This Law

aims to ensure the fulfillment of children's rights so that they can live, grow, develop, and participate optimally in accordance with human dignity, and receive protection from violence and discrimination, for the realization of Indonesian children who are quality, noble and prosperous (Duadji \& Tresiana, 2018).

In 2004, the Indonesian Commitment was further outlined in the "National Program for Indonesian Children (PNBAI) 2015", which was followed up by the Ministry of Women's Empowerment and Child Protection (KPP-PA) of the Republic of Indonesia in the form of developing child-friendly districts / cities (KLA) in 2006 (Muhammad Elwan, 2019).

It is hoped that the development of Kediri City to be child-worthy is expected to improve the welfare of children who are not only in a material or physical dimension, but also spiritually or spiritually, allowing children to explore limited freely in achieving ideal goals, controlled and supported by a child-friendly environment so that they can actively participate. and contribute to the development process creatively, innovatively, and constructively, in a system of life (also governance) that is safe and secure, harmonious and peaceful, in addition to the fulfillment of basic needs for clothing, food, shelter, education, health, free from fear and shackles. discrimination, as well as being free from exploitation and violence, with increasingly qualified human resources physically, psychologically and intellectually (Darwin, 2018).

To realize the development of Kediri City Towards a Child-Friendly City, as an institution in Kediri City, a Child Friendly City Task Force has been formed through the Decree of the Mayor of Kediri Number 188.45 / 349 / 419.16 / 2012 concerning the Formation of a Task Force for a Child Friendly City Task Force for the City of Kediri, which consists of SKPD. related to the Kediri City Government, vertical agencies, academics, groups of professional organizations, Community Figure Groups, Child Protection Institutions, and other community organizations that are concerned about child development in Kediri City (Darwin, 2018).

The Task Force Team is grouped into 5 (five) clusters consisting of the Civil Rights and Freedom Cluster, the Family Environment and Alternative Care Cluster, the Basic Health and Welfare Cluster, the Education Cluster, the Use of Free Time and Cultural Activities, and the Special Protection Cluster. Each team divided into these clusters must work together and work together in realizing a Child Friendly City according to the indicators in their respective clusters. The purpose of establishing the KLA Task Force Team for Kota Kediri is to accelerate the realization of a Child Friendly City in Kediri City by strengthening synergy and coordination and carrying out their respective functions and duties.

Although various child-friendly city / district developments have been carried out aimed at reducing or eliminating children's problems, it turns out that the issue of children has not been able to become the center of attention development in the district / city. The implementation of development in the regions has so far emphasized economic, political 


\section{STRADA Jurnal Ilmiah Kesehatan}

DOI: $10.30994 /$ sjik.v9i2.535

ISSN: 2252-3847 (print); 2614-350X (online)

Vol.9 No.2 November 2020 Page. 1788-1796

and infrastructure development, without considering the child's best interests in decision making. Many development policies have not taken sides in children, so that the bias in its implementation and the government bureaucracy also seems to have not been responsive to children because there is no awareness of policy makers or bureaucratic leaders on the importance of child issues in policies that are compiled (Duadji \& Tresiana, 2018).

In order to anticipate potential failures that could disrupt the process of developing a child-friendly city, the government needs to change its governance pattern by strengthening it through cooperation and developing models of communication processes and collective action with other institutions. The focus of management change is on the process planning and formulating policies that were originally carried out by the government itself, were changed to involve other multi-stakeholders. A governance model that involves multistakeholders to make public decisions is called collaborative governance (Pia Christencen and Margaret O'Brien, 2003).

This study aims to explain 2 (two) things, namely: 1) mapping of the main problems of children in development and the potential that exists in the area from the aspects of policies, institutions / organizations of children that can be developed; 2) developing a collaborative governance model in the development of a child-friendly city in Kediri.

\section{METHODS}

The research method used is descriptive qualitative. The data used are primary and secondary data. Secondary data were obtained from local governments in the form of relevant documentation. Primary data obtained from interviews and observations. The collection technique was carried out by: 1) observation; 2) in-depth interviews; 3) documents; and 4) Focus Group Discussion (FGD). The data collected were analyzed by means of qualitative analysis, with an interactive model from Miles and Huberman (Miles, B. Mathew, 1992). Primary data is in the form of words, speech and actions or behavior of informants, as well as secondary data obtained from various documents, archives, journals, scientific works, statistical data and others. The research location was carried out in the city of Kediri, which has 3 districts and 46 villages, with the target subject of several government and non-government agencies.

\section{RESULTS AND DISCUSSION Civil Rights and Freedoms}

Based on data from the Population Administration Information System of the Department of Population and Civil Registration of Kediri City as of December 31, 2014, the number of children aged 0-19 years was 86,918, consisting of 44,621 boys and 42,297 girls.

Of the 86,918 children registered, 68,601 children had birth certificates or $78.93 \%$ and 18,317 children did not have birth certificates or $21.07 \%$.

Although compared to previous years, the coverage of ownership of deeds for children in Kota Kediri shows an increasing trend based on data from the Department of Population and Civil Registration of Kediri City, the coverage of ownership of child birth certificates in Kota Kediri in 2014 was only $78.93 \%$.

This shows that the achievement of having a child's birth certificate in Kediri has not met the KLA indicator target of $100 \%$.

This increase in the coverage rate is the result of the efforts made by the Kediri Municipal Dispendukcapil to increase the coverage of registration and ownership of birth certificate quotes. The process of obtaining and issuing birth certificates for children in Kediri City is also free of fees. The administration of child birth certificates has even been exempted from 


\section{STRADA Jurnal Ilmiah Kesehatan}

DOI: $10.30994 /$ sjik.v9i2.535

ISSN: 2252-3847 (print); 2614-350X (online)

Vol.9 No.2 November 2020 Page. 1788-1796

fees for children's birth certificates since 2012, based on Kediri City Regional Regulation Number 4 of 2012 concerning Administration of Population and Retribution for Reimbursement of Printing Identity Cards and Civil Registration Certificates, before nationally in 2013 issued Law Number 24 of 2013 concerning Population Administration by the Ministry of Home Affairs with the imposition of a free fee in making population documents starting in early January 2014.

\section{Children And Health Issues}

Infant Mortality Rate (IMR)

Data on Infant Mortality Rate in Kediri City in 2014 were 25 babies out of 4,793 live births. Meanwhile, the number of deaths for the current year (2015) was 6 people.

\section{Types of Diseases Often the Main Cause of Infant Mortality}

Types of diseases with the most common causes of infant mortality in Kediri are respiratory problems, diarrhea, LBW, congenital disorders and asphexia.

Efforts made by the Kediri City Health Office to reduce infant mortality is by providing counseling to mothers and families during pregnancy so that people understand more about nutrition and provide complementary food assistance to pregnant women. To reduce LBW cases, it is carried out by carrying out case management quickly and accurately, one of which is to refer LBW babies or babies at risk to referrals with more complete facilities.

On November 14, 2014, a Movement Team for Suppressing Maternal and Infant Mortality Rates was formed which was proclaimed by the Head of the PKK Driving Team for the City of Kediri. This team is a collaboration between the Health Office and Posyandu cadres and related work units (BPPKB, Hospital, Food Security Office, etc.) in providing assistance to pregnant women during pregnancy, visiting Risti patients' homes. By strengthening referral networks in maternity services and services for children, it is hoped that it can reduce the maternal and infant mortality rate in the following year.

The data above shows a decrease in the number of infant deaths in 2015 compared to 2014 and is below the National Infant Mortality Rate. This shows the KLA indicator has been fulfilled. The effort that must be done in the future is to increase the program to reduce the infant mortality rate so that it decreases from year to year

\section{Prevalence of Malnutrition, Malnutrition, Stunting and Overnutrition in Toddlers}

The prevalence of malnutrition among children under five in Kota Kediri in 2014 was $0.8 \%$. Meanwhile, the prevalence of malnutrition in children under five in 2014 was $3.5 \%$. Meanwhile, the prevalence of stunting in 2014 was $4.4 \%$ and the prevalence of children with excess nutrition was $1.2 \%$. Meanwhile, the prevalence of malnutrition in the current year (2015) was $0.5 \%$, malnutrition was $2.3 \%$, stunted children were $0 \%$ and overnutrition was $1.2 \%$.

Efforts that have been made by the Kediri City Health Office in suppressing undernutrition or malnutrition are monitoring through Posyandu if there are BGM toddlers, immediately referred to the Puskesmas to verify their weight and TB, if they are in the under nutrition category, they will get PMT recovery and assistance from the Puskesmas

\section{Exclusive Breastfeeding Presentations}

The percentage of exclusive breastfeeding in Kediri City in 2014 was $65.97 \%$ but in 2015 it decreased to $64 \%$.

The number of breastfeeding counselors in Kediri is 16 counselors, with details of 9 counselors in 9 health centers spread across 3 sub-districts, 5 counselors in hospitals and 2 


\section{STRADA Jurnal Ilmiah Kesehatan}

DOI: $10.30994 /$ sjik.v9i2.535

ISSN: 2252-3847 (print); 2614-350X (online)

Vol.9 No.2 November 2020 Page. 1788-1796

counselors in the Health Office. Meanwhile, there are 14 lactation rooms in Kediri, which are spread across 9 health centers, 9 rooms, 1 room for the Health Office, 1 government hospital and 3 public places (Kediri Town Square, Kediri Mall and Station).

The number of lactation rooms from the data above shows that only the work area of the Health Office has lactation rooms and a small number of public places. In the future, it is hoped that there will be policies that support and facilitate breastfeeding mothers, for example policies that require government-owned and private offices to provide lactation rooms or limit the distribution of formula milk.

\section{Percentage of Child Friendly Puskesmas}

In Kediri City, there are 9 health centers spread across 3 sub-districts, including: Mrican Health Center, Campurejo Health Center, Sukorame Health Center, North City Health Center, Southern City Health Center, Balowerti Puskemas, Pesantren I Health Center, Pesantren II Health Center and Ngletih Puskemas. Among the nine health centers, 2 of them are projected as Child Friendly Puskesmas, namely the Campurejo Health Center and the North Region Puskesmas, considering that these Puskesmas are a Puskesmas capable of administering KTA (Violence Against Children).

\section{Percentage of Complete Basic Immunization}

Immunization coverage data in 2015 has increased from 2013. In 2014 there were 4,744 births, babies who received complete basic immunization were 4,713 people. So that the complete basic immunization coverage is $99.35 \%$. And in 2013 from 4,753 births, babies with complete basic immunization were 4,385 (92.3\%).

Kelurahan in Kediri City with UCI (Universal Child Immunization) as many as 45 Kelurahan or $97.82 \%$ of all Kelurahan in Kediri City, with the number of children under five who received complete basic immunization in 2014. Complete basic immunization coverage data in Kota Kediri is above the standard KLA indicator $80 \%$ with a target of complete basic immunization coverage in 2018 in the RPJMD of $89 \%$.

\section{Institutions Providing Adolescent Reproductive Health Services}

In Kediri City, there are 9 health centers which are PKPR (Youth Care Health Services) puskesmas. PKPR puskesmas activities include providing IEC, medical services and counseling. Counseling activities can be carried out by puskesmas officers both at the puskesmas and outside the building (school). Of the 9 puskesmas that have separate youth counseling rooms are the Sukorame Community Health Center, the North Region City Health Center, the Islamic Boarding School 2 Puskesmas. For Mrican, Campurejo, South City, Balowerti, Islamic Boarding School 1 and Ngletih Puskesmas

\section{Institutions Providing Mental Health Services}

Mental health service institutions located in 9 puskesmas in Kediri City, Gambiran Hospital, RS. Bhayangkara Kediri and RS. Baptist City

Kediri and Lab. Applied Psychology STAIN Kediri

From the data above, it shows that in Kediri City there are 11 Adolescent Reproductive Health Service Institutions, 4 child drug victims services and 15 HIV-AIDS infected children services and 13 Mental Health Services. From these data, there is no data on the number of children served, apart from data from services for children infected with HIVAIDS. The thing that needs to be considered is the ease of access to these services for children, including information on the existence of service institutions including a 


\section{STRADA Jurnal Ilmiah Kesehatan}

DOI: $10.30994 /$ sjik.v9i2.535

ISSN: 2252-3847 (print); 2614-350X (online)

Vol.9 No.2 November 2020 Page. 1788-1796

comfortable or friendly service environment for children so that socialization is needed about the existence and urgency of services to children.

\section{No Smoking Area (KTR)}

Based on the Mayor of Kediri No. 392 of 2003 stipulated smoke-free areas covering educational facilities and health facilities in the area of Kediri City. From the standard KLA indicator, some of the areas recommended as non-smoking areas are already owned by the City of Kediri. What needs to be improved is that the definition of a No Smoking Area is not only a smoking ban but also a prohibition on advertising and selling cigarette products. In addition, new regulations are needed to strengthen the procurement of smoke-free areas and expand the area not only in school areas or health services but also in public transportation, places of worship, workplaces, public places with children.

\section{Children and Child Issues}

\section{Institutions Providing Services for Child Victims of Drugs}

The Process of Diversion Seeking for Children in Conflict with the Law

In 2014 there were 4 cases of children under 12 years of age who were in conflict with the law and none of these were assigned to participate in social rehabilitation at the LPKS. Meanwhile, there were 4 cases of diversion at the investigation level, and 1 child was detained due to repeated crimes. Meanwhile, the number of children who failed to be diversified and transferred to the prosecution was 6 .

In 2015 there were 18 cases involving children as perpetrators, consisting of 9 cases of abuse, 2 cases of sexual violence and 7 cases of theft. This figure shows an increase in the number of cases from 2014 to 8 cases. The number of children involved as perpetrators in 2015 was 23, of which 10 were completed by the Diversion process

\section{Early Childhood Education Participation Rate}

Based on the KLA indicator, the PAUD APK value in Kediri City is far above the 2014 National APK of 75\%. In addition, Kediri City has 222 Integrative Holistic PAUD from 248 existing PAUD, what is meant by Integrative Holistic PAUD is early childhood education that integrates all aspects and values in education such as moral, ethical, religious, psychological, philosophical, and social values. in a comprehensive unity between soul and body as well as material and spiritual aspects to meet the essential needs of the child

\section{Children's Group Facilities and Forums}

The children's forum in Kediri is called Paguyuban Konco Kediri (PAKORI) which was formed on 20 October 2012 with a membership of junior high and high school students and the majority of whom are activists of intra and extra school activities. DPA-PAKORI is a communication forum managed by children who represent individuals and organizations or groups of children in the city of Kediri that are fostered by the government.

DPA Pakori is facilitated and fostered by the Kediri City Women's Empowerment and Family Planning Agency and the Kediri City Child Protection Agency (LPA) as government partners. The formation of DPA Pakori aims to accommodate and channel children's aspirations in obtaining children's basic rights in Kediri City.

One of the Children Groups in Kediri City is the Student Council Organization (OSIS) which was formed in 2014 with the members of the Student Council Management for SMP-SMA throughout Kediri. PAGUYUBAN MANAGEMENT OF OSIS as a forum for 


\section{STRADA Jurnal Ilmiah Kesehatan}

DOI: $10.30994 /$ sjik.v9i2.535

ISSN: 2252-3847 (print); 2614-350X (online)

Vol.9 No.2 November 2020 Page. 1788-1796

communication managed by children who voice the interests of students in the city of Kediri is facilitated and fostered by the Kediri City Education Office.

This group of children under the guidance of the Family Planning Division of the Women Empowerment and Family Planning Agency of Kediri City has a vision and mission that is in line with its coaches, namely to carry out Reproductive Health Communication, Information and Education for Adolescents. One of their main activities is to become Peer Counselors for fellow teenagers who want to find out about Kespro issues or to consult if they experience Kespro problems. In addition, they also carry out socialization in the context of preventing Early Marriage, Early Pregnancy and HIV AIDS.

There are many Scout Units under the auspices of the SKPD and other institutions for children groups who have an interest in the field of scouting. For example the Family Planning Work Unit Scouts (Saka), the Saka Bhakti Husada Scouts, the Saka Bhayangkara Scouts, the Dirgantara Saka Scouts whose guidance and funding are through their respective Regional Work Units.

There are still many other groups of children at the City, Subdistrict and Kelurahan levels that are spread across Kediri City. However, there is no data related to activities, interests or numbers. In addition, there is no program that can unite children's groups in Kediri City so that DPA -Pakori can truly become a forum for children's brainstorming and represent children's voices in the development process in Kediri City.

Although DPA-PAKORI has been involved in the formulation of local government policies related to children, such as the Mayor's Regulation on Child-Friendly City Development, the Mayor's Regulation on General Guidelines. Children's Participation in Development in Kediri City, as well as the Mayor's Regulation concerning the Prevention of Violence and Sexual Exploitation of Children at Night Entertainment Places, Karaoke, Massage Parlors, Stalls, and Hotels in Kediri City (currently still in the process of revision) but their involvement in every planning stage through the stages of the Development Planning Musayawarah (Musrenbang) from the Kelurahan level to the City level, it has not been optimally implemented

\section{Age of First Marriage Under 18 Years}

From the data on the marriage of women under 21 years of age, cases of women under 18 years of age can be further sorted which in various Lex Specialist laws such as Law Number 35 of 2014 concerning Amendments to Law Number 23 of 2002 Concerning Child Protection and Law Law Number 11 of 2012 concerning the Child Criminal Justice System referred to as a child is a person who is not yet 18 years old. Of the total cases of female marriage under 21 years of age in 2014, there were $21.5 \%$ cases of child marriage or 60 cases. Meanwhile, in 2015 there were $16,5 \%$ or 20 cases of marriage involving children.

The majority of cases of marriage involving children are caused by the fact that the female partner has experienced an unwanted pregnancy. From the number of cases that occurred, only 1 case of child marriage was caused by the intention of the parents or guardian to marry off their child to the prospective groom who had been chosen or the child was forced to marry.

The research data conducted by LPA Kota Kediri above shows a sharp decline in the number of marriages in 2015 compared to 2014, but the causes or backgrounds of child marriage must immediately get a solution, given the cases of sexual violence involving children as victims and perpetrators. increased in 2015. 


\section{STRADA Jurnal Ilmiah Kesehatan}

DOI: $10.30994 /$ sjik.v9i2.535

ISSN: 2252-3847 (print); 2614-350X (online)

Vol.9 No.2 November 2020 Page. 1788-1796

\section{Improving the Welfare of Children from Poor Families}

One of the Poverty Alleviation Programs under the Ministry of Social Affairs is the Family Hope Program. Data on the number of children from poor families originating from PKH program recipients shows a decrease in the number from 4677 in 2014 to 4306 in 2015 (Table 3.14). Meanwhile data from other poverty alleviation programs such as BOS and BSM from the Education Office, PNPM Mandiri, PMT Recovery for children with malnutrition prevalence from poor families has not been compiled.

\section{CONCLUSION}

Based on the data processing of interviews and observations, it was found important important aspects as a determinant of the success of the development of child-friendly city policies in Kediri, including: Mapping of various issues and problems of children that occurred in Kediri City covers various fields of development, ranging from civil, health issues, law, education, social and child development. To solve the problem of children, it is necessary to strengthen the development policy model for Child Friendly Cities (KLA). The institutional potentials that are owned are social capital to solve children's problems. To strengthen the development of a Child Friendly City, it is necessary to develop a collaborative governance model, based on face-to-face dialogue. This model then contributes to the formulation of child-friendly city development planning / policies.

It is suggested that the resulting collaborative governance model be followed up by the Kediri City Government, in the form of strengthening dialogue space, forming a dialogue forum that involves all children's institutions and organizations in Kediri City collaboratively, strengthening policies, socializing the importance of child problems to be an important part of development.

\section{REFERENCES}

Ambar Teguh Sulistyani. (2004). Kemitraan dan Model-Model Pemberdayaan. Graha Ilmu. Anita Lie. (2008). Cooperative Learning : Mempraktikan Cooperative Learning di RuangRuang Kelas. Grasindo.

Ansell, Chris, dan A. G. (2008). Collaborative Governance in Theory and Practice. Journal of Public Administration Research and Theory, 4, 543-571. https://doi.org/https://doi.org/10.1093/jopart/mum032

Darwin, M. (2018). Kata Pengantar. Populasi, 25(2). https://doi.org/10.22146/jp.36215

Duadji, N., \& Tresiana, N. (2018). Kota Layak Anak Berbasis Collaborative Governance. Sawwa: Jurnal Studi Gender, 13(1), 1. https://doi.org/10.21580/sa.v13i1.2201

Innes, J. E., dan D. E. B. (2010). Beyond Collaboration Democratic Governance for a Resilient Society." In Planning with Complexity Complexity, An Introduction to Collaborative Rationality or Public Policy. Routledge.

John Ahier. (1988). Industry Children and the Nation: an Analysis of National Identity in School Textbooks (Philadelphia (ed.)). The Falmer Press.

MIles, B. Mathew, dan A. M. H. (1992). Analisis Data Kualitatif: Buku Sumber Tentang Metode-Metode Baru. UI Press.

Muhammad Elwan, L. O. (2019). Rekomendasi Kebijakan Program Kota Layak Anak Di Kota Kendari. Journal Publicuho, 2(1), 15. https://doi.org/10.35817/jpu.v2i1.5987

Novika, B. (2018). Optimalisasi Pelaksanaan Kebijakan Pengembangan Kota Layak Anak Dan Implikasinya Terhadap Ketahanan Sosial Masyarakat (Studi Di Kecamatan Gedongtengen, Kota Yogyakarta Provinsi DI Yogyakarta). Jurnal Ketahanan Nasional, 24(2), 192. https://doi.org/10.22146/jkn.30843 


\section{STRADA Jurnal Ilmiah Kesehatan}

DOI: $10.30994 /$ sjik.v9i2.535

ISSN: 2252-3847 (print); 2614-350X (online)

Vol.9 No.2 November 2020 Page. 1788-1796

Patilima, H. (2017). Kabupaten Kota Layak Anak. Indonesian Journal of Criminology, 13(1), 229091.

Pia Christencen dan Margaret O'Brien. (2003). Children in the City Home, Neighbourhood and Community (Routledge Falmer (ed.)).

Roza, D., \& S, L. A. (2018). Peran Pemerintah Daerah Untuk Mewujudkan Kota Layak Anak Di Indonesia. Jurnal Hukum Ius Quia Iustum, 25(1), 198-215. https://doi.org/10.20885/iustum.vol25.iss1.art10

Sri Anitah dan Janet T Manoy. (2007). Strategi Pembelajaran Integral. Universitas Terbuka.

UNICEF. (2004). Building Child Friendly Cities: A Farmwork for Action (Innocenti Research Centre (ed.)).

Wayne Cascio F. (2006). Managing Human Resources, Productivity, Quality of Work Life, Profits (McGrae-Hill (ed.)). 